\title{
"ULALUME" \\ Um jogo entre o som e o sentido de Murilo Mendes
}

\author{
Luciana Stegagno Picchio
}

1. Quando, em Janeiro de 1971, Murilo Mendes me entregou, com uma afetuosa dedicatória, como sempre, o volume da sua Convergência que acabava de ser publicado pela Livraria Duas Cidades de São Paulo e que continha poemas escritos entre 1963 e 1966, eu confirmei-me na convicção de que, nos anos de Roma, a poesia do nosso poeta tinha tido (não quero dizer sofrido, porque não se tratara de sofrimento, mas de nova conquista) uma completa revolução. Uma revolução que se revelava não só nos Grafitos e Murilogramas, as duas primeiras seções do livro dedicadas respectivamente a Ruggero Jacobbi e, com minha grande emoção, a mim, testemunhas cotidianas da sua progressiva "mudança". Mas que se revelava sobretudo na última parte, naquela Sintaxe, consagrada pour cause "à fabulosa memória de Oswald de Andrade", em que se recolhiam os textos mais decididamente experimentais. A experimentação era basicamente de caráter formal, centrada no estudo e no emprego das palavras no seu aspecto gráfico e fónico, com experiências de transgressão, ruptura, nova organização e montagem de segmentos e de sentidos, cunhagem de neologismos, no limite da "invenção" poética. Depois do Murilo da poesia em pânico, do Murilo visionário e apocalíptico dos seus grandes livros, depois do Murilo "neo-romântico" da Contemplação de Ouro Preto, do Murilo retratista de homens e paisagens da Siciliana e de Tempo Espanhol, tínhamos o Murilo da experimentação verbal poética e reveladora, dirigida a subtrair o instrumento linguístico ao automatismo do uso codidiano. Embora Manuel Bandeira o tivesse definido como "um 
dos quatro ou cinco bichos de seda da poesia brasileira, isto é os que tiravam tudo de si mesmo", a última fase da sua poesia guardava os sinais por um lado da sua freqüentação das vanguardas européias, francesa e italiana, do seu interesse pelo estruturalismo, do seu convívio com os poetas e os artistas italianos presentes em 1961 na antologia de I novissimi, apresentada por Alfredo Giuliani e depois reunidos no "Grupo 63". Das vanguardas italianas Murilo herda naquele período o conceito da identidade entre ideologia e linguagem que um poeta e teórico como Eduardo Sanguineti condensa assim: "Não existe originalidade de visão ideológica e de perspectiva realística que possa ser garantida por outra coisa que não seja a linguagem, na medida em que a realidade de uma obra, evidentemente e imediatamente é uma realidade linguística". Por outro lado, na praxe de Murilo Mendes houve sempre, nos anos italianos, uma contínua atenção às manifestações poéticas do Brasil: a começar pela poesia concreta, de Haroldo e Augusto de Campos e de Décio Pignatari, e sobretudo pelo exemplo de invenção poética, fora de qualquer molde de tradição, do mestre-discípulo João Cabral de Melo Neto. Era um processo a que naquela altura nenhum grande poeta contemporâneo, a começar pelo Drummond da Lição de Coisas, se substraía. Sem contar a extraordinária lição de invenção vocabular que saía dos escritos de Guimarães Rosa. Lembro-me de uma daquelas "palestras de poesia", realizada em Roma nos anos sessenta, quando, na presença de escritores e de artistas amigos que bem conheciam o lado "católico" do nosso poeta, alguém de brincadeira lhe perguntara que livro levaria ele para a prisão ou para uma metafórica ilha deserta e, quando todos esperavam uma resposta ortodoxa que incluísse talvez a Bíblia ou o Evangelho, ele declarara sem hesitação: "Grande Sertão: Veredas". O Exergo da Convergência apresentava o poeta-Orfeu que, embora "lacerado pelas palavras-bacantes, ... impedia a sua diáspora, mantendo-lhe o nervo e a ságoma". E todos os textos-poemas da Sintaxe represen- 
tavam a tentativa de manter o nervo, senão a ságoma original, de palavras exploradas em todas as suas possibilitades de emprego, na sua capacidade de originar novos sentidos quando percutidas, como diamantes, pela luz da invenção, analógica, homófona, a que não tinham sido extranhos os jogos-experimentos dos surrealistras (“As válvulas da valva. As válvulas da vulva. As válvulas da viola. As válvulas do vulgo. As válvulas do povo. As válvulas do polvo. As válvulas da valsa. As válvulas da viúva"). Em que, de repente, como num fabuloso Cadavre exquis, emergiam à luz associações latentes e inesperadas. Não se trata da proclamada superioridade do significante sobre o significado, mas da consciência da lição estruturalista de que "tudo significa".

2. Não fiquei portanto admirada por ter encontrado num livro de tão relevantes recorrências fónicas e de tão bizarras conexões de sentido, um título como Ulalume, capaz de evocar, com suas tonalidades acústicas sombrias, toda a magia dos poemas góticos de Edgar Allan Poe. A poesia de Poe, bem o sabemos, fora objeto de culto para grandes poetas e grandes escritores como Baudelaire e Mallarmé, Giovanni Pascoli, Machado de Assis e Cortázar. E em Ulalume, publicada em 1847 e considerada um dos mais belos poemas do autor do Corvo, ponto extremo alcançado pelo lado místico do seu gênio, o elemento simbólico já não aparecia como intencionalmente sobreposto, mas capaz de gerar, através da harmoniosa sugestão dos versos, a fusão da dor pessoal no universal. Pela sua formação "latina", Murilo não era porém frequentador habitual de enfeitiçadas florestas de Weir, de sombrios lagos de Auber e, como babitué de iperurânios, achava-se mais à vontade debruçado na janela do Caos, de que passeando numa solitária noite de outubro ao lado de Psiche, sob os ciprestes de uma alameda nórdica e cinzenta. $\mathrm{Na}$ sua obra existiam, como em todas as vidas, lembranças de meninas, mulheres, mortas jovens que tinham dei- 
xado uma grande ferida na sua alma. Mas que plasticidade, que definição física entre estas mortas brasileiras e as evanescentes Lenore, Annabel Lee e Ulalume dos sonhos góticos de Poe! "A costureira, moça, bonita, ancas largas, os seios estourando debaixo do vestido (os olhos profundos faziam a sombra na cara), morreu".

O único laço entre Poe e Murilo Mendes, que eu poderia imaginar, seria Fernando Pessoa. O Fernando Pessoa das meninas mortas deitadas na sua alma como a irmã morta levada a Lisboa no mesmo navio que o restituira à pátria. Eu Fernando Pessoa tradutor de Poe e recriador em ritmos e ressonâncias portuguesas, em jogos de "nunca mais" e "da linda que eu soube amar", dos "nevermore" e dos "The Beatiful Annabel Lee" do poeta americano.

Pessoa traduzira os três poemas das meninas mortas de Poe: The Raven, Annabel Lee e Ulalume. Traduzira-as como ele próprio declara, "não tanto pelo grande valor intrínseco que eles possuem, mas porque representam um desafio permanente para os tradutores". Traduzira-os com resultados alternos, mas sempre com aquela liberdade que lhe permitir conservar a "sonoridade profunda e lúgubre" dos versos de Poe citada por Baudelaire.

Fora essa sonoridade, é só essa, a interessar Murilo Mendes. A sua citação de Ulalume, no livro da Sintaxe, limita-se ao título e a um exercício, bastante desligado do poema de Poe, sobre as possíveis sugestões do seu emprego:

Ulalume

O livro de Ulalume. O leque de Ulalume. Os laços de Ulalume.

A luva de Ulalume. A lenda de Ulalume.

com o corolário fónico

O ulo. O lençol. O lenho. O lume. 
Num poema italiano dedicado a Montale e incluído no volume publicado postumamente, em 1977, Ipotesi, Murilo tinha voltado a revelar a sua fascinação medrosa para as palavras com ressonâncias profundas e lúgubres de U (e não importa qual fosse a original pronúncia inglesa do nome Ulalume, pois Murilo, como Pessoa, sempre leu e pronunciou Ulalume à portuguesa ou, se quisermos, à italiana). A palavra desagradável em $u$ era, no caso da poesia de Montale, upира, nome de uma ave de longo bico e voz monótona que toda a gente, em virtude do seu nome em $u$ pensa ser ave noturna e que afinal é animal diurno, como, a seu pesar, iria descobrir Murilo:

MONTALE

\author{
Upupa è una parola \\ che incontrai molti anni fa \\ in un testo di Montale: \\ secondo il vocabolario \\ una parola diurna \\ e non notturna \\ come credeva il Foscolo.
}

Non la conoscevo prima

e mi ha urtato.

Não imaginemos portanto, como se poderia concluir, uma fascinação de Murilo para o mundo áspero e crepuscular de Edgar Allan Poe. Ulalume, como ирира, para o poeta brasileiro Murilo Mendes foi unicamente uma ocorrência fónica, uma lenda em U. 


\section{Nota bibliografica}

Murilo Mendes, Convergência. 1-Convergência 2-Sintaxe 1963-1966, São Paulo, Livraria Duas Cidades, 1970: o poema "Ulalume”, p.147 da Sintaxe.

Murilo Mendes, Poesia completa e prosa, Org. de L. Stegagno Picchio, Rio de Janeiro, Editora Nova Aguilar, 1994: o poema "Ulalume", p. 711.

Murilo Mendes, Ipotesi, a cura di L. Stegagno Picchio, Milano, Guanda, 1977: o poema "Montale", p.13. Na Poesia completa, cit.: o poema "Montale", p. 1558.

Para Fernando Pessoa e Poe, v. Badia Bourennane Baker, "Fernando Pessoa and Edgar Allan Poe", in Arquivos do Centro Cultural Português, vol. XV, Paris, Fundação Calouste Gulbenkian, 1980. Os textos e um amplo comentário em Edgar Allan Poe The Raven, Ulalume, Annabel Lee, traduzione portoghese di Fernando Pessoa, a cura di Paolo Collo, Torino, Giulio Einaudi Editore, 1995. 